\title{
ARTÍCULOS
}

\section{INFLUENCIA DEL CONTEXTO INTERNACIONAL SOBRE LA FIRMA DEL TRATADO DE RECONOCIMIENTO DOMINICO-ESPAÑOL EN 1855}

\author{
Influence of the international context
}

on the signing of the Dominican-Spanish recognition treaty in 1855

\author{
Luis Alfonso Escolano Giménez \\ Universidad IE, Madrid \\ luisescolano@gmail.com \\ Orcid: 0000-0002-4824-8342
}

Recibido: 25-05-2020 - Aceptado: 21-07-2020

\section{Cómo citar este artículo/Citation:}

Luis Alfonso Escolano Giménez, "Influencia del contexto internacional sobre la firma del tratado de reconocimiento dominico-español en 1855”, Hispania Nova, 19 (2021): 36 a 71 .

DOI: https://doi.org/10.20318/hn.2021.5875
Copyright: (C) HISPANIA NOVA es una revista debidamente registrada, con ISSN 1138-7319 y Depósito Legal M 9472-1998. Los textos publicados están -si no se indica lo contrario- bajo una licencia Reconocimiento-Sin obras derivadas 3.0 España de Creative Commons. Puede copiarlos, distribuirlos y comunicarlos públicamente siempre que cite su autor y la revista y la institución que los publica y no haga con ellos obras derivadas. La licencia completa se puede consultar en: http://creativecommons.org/licenses/by-nd/3.0/es/deed.es
Resumen: El periodo alrededor del tratado de reconocimiento entre España y la República Dominicana en 1855 es fundamental para estudiar las causas de la intervención extranjera en el país caribeño, pues revela las dinámicas internas y externas que condujeron a una grave inestabilidad derivada de las luchas entre grupos locales, apoyados por diferentes países con sus propios objetivos. Bajo el pretexto de mediar entre haitianos y dominicanos, las principales potencias rivalizaron por aumentar su influencia sobre el ejecutivo de Santo Domingo, al principio mediante el establecimiento de relaciones diplomáticas. Aunque las primeras iniciativas del gobierno dominicano para llegar a un acuerdo con España fueron rechazadas por el gabinete de
Madrid, este decidió finalmente establecer relaciones con el de Santo Domingo para actuar sobre el terreno y obstaculizar el expansionismo estadounidense en la República Dominicana, ya que las autoridades españolas de Cuba y Puerto Rico lo consideraban una amenaza para la preservación de dichas islas.

Palabras clave: Relaciones internacionales (siglo XIX), República Dominicana, expansionismo norteamericano, injerencia extranjera, relaciones dominico-españolas, política exterior española. 


\begin{abstract}
The period around the recognition treaty between Spain and the Dominican Republic in 1855 is essential to study the causes of foreign intervention in the Caribbean country, since it reveals both the internal and external dynamics that led to serious instability arising from the struggles among local groups that were supported by different countries with their own goals. Under the pretext of mediating between Haitians and Dominicans, the main powers vied to increase their influence over the Santo Domingo executive, initially by establishing diplomatic relations. Although the first initiatives of the Dominican government to reach an agreement with Spain were rejected by the Madrid cabinet, it eventually decided to establish relations with that of Santo Domingo in order to act on the ground and hinder U.S. expansionism in the Dominican Republic, since the Spanish authorities in Cuba and Puerto Rico considered it a threat to the preservation of these islands.
\end{abstract}

Keywords: International relations $\left(19^{\text {th }}\right.$ century), Dominican Republic, U.S. expansionism, foreign interference, Dominican-Spanish relations, foreign Spanish policy.

\section{INTRODUCCIÓN}

Los primeros intentos de anexionar la totalidad o una parte del territorio dominicano a otro país se produjeron ya durante la etapa anterior a la llamada independencia efímera de Santo Domingo, proclamada de forma incruenta el 1 de diciembre de 1821. En efecto, la gente de color en algunas poblaciones fronterizas planteó incluso su anexión al reino constituido por Henri Christophe en el norte de Haití, aunque afortunadamente para la metrópoli las autoridades dominicanas descubrieron a tiempo el complot y lo abortaron. "El componente racial de la revuelta, la proximidad de la amenaza haitiana y los conatos anexionistas reseñados motivaron la dura represión de los cabecillas", quienes fueron condenados a muerte. Pinto Tortosa subraya que mediante este castigo, el gobernador de Santo Domingo "intentó disuadir al resto de esclavos dominicanos de imitar a aquellos conspiradores", si bien con ello

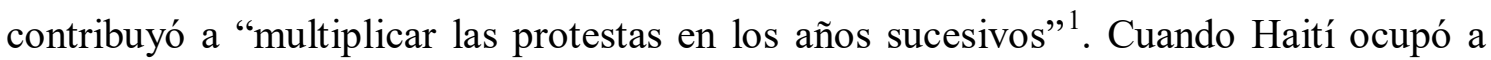
comienzos de 1822 el estado recién independizado sus tropas no encontraron resistencia alguna, en gran parte debido a que el nuevo régimen no había abolido la esclavitud.

\footnotetext{
${ }^{1}$ Antonio Pinto Tortosa, Santo Domingo: una colonia en la encrucijada 1790-1820 (Madrid: Foro para el Estudio de la Historia Militar de España, 2017), 269-270.
} 
E1 27 de febrero de 1844 la República Dominicana se separó por fin de Haití, y desde entonces el país fue objeto de numerosas injerencias procedentes de las principales potencias que tenían intereses en el Caribe: Estados Unidos, Gran Bretaña, Francia y España. De hecho, estas intervenciones extranjeras en la política interna dominicana fueron consecuencia directa o indirecta de la rivalidad existente entre los países europeos, por un lado, y Estados Unidos, por otro. No obstante, los primeros mantuvieron diversas posturas entre sí respecto a la expansión norteamericana, sobre todo en función de las cambiantes circunstancias de cada coyuntura, tal como se analiza con mayor detalle a lo largo de este trabajo.

A causa de las luchas por el poder entre los dos principales caudillos locales, Pedro Santana y Buenaventura Báez, esa injerencia se vinculó entonces más que nunca a los asuntos internos. Ha de subrayarse asimismo la importancia de los efectos de un proyecto de tratado entre la República Dominicana y Estados Unidos, el cual permitía la concesión de un puerto a la armada norteamericana en la costa septentrional de la isla, concretamente en la estratégica bahía de Samaná. Dicha eventualidad representaba una amenaza para Haití, que temía posibles ataques e incluso ser invadido por Estados Unidos si este país, como potencia esclavista, consideraba ventajoso para su propia expansión ocupar el territorio haitiano.

En tal tesitura, la resistencia armada de la República Dominicana frente a su vecino, con varias campañas bélicas desde 1844 hasta 1856, fue otra de las principales razones del comienzo de la intervención extranjera en los asuntos insulares, con el pretexto de una mediación diplomática entre ambos países. El entonces presidente vitalicio de Haití, Faustin Soulouque, quien poco más tarde se coronó emperador y reinó como Faustino I entre 1849 y 1859, lanzó un ataque en marzo de 1849 contra la República Dominicana, para impedir que esta fuese reconocida por Francia y Gran Bretaña. Sin embargo, su intento de invasión se saldó una vez más con la estrepitosa derrota del ejército haitiano en la batalla de Las Carreras, que tuvo lugar el 21 de abril del mismo año.

En efecto, los comisionados que el ejecutivo de Santo Domingo había enviado a Europa lograron firmar un tratado con Francia el 22 de octubre de 1848, que finalmente no llegó a ser ratificado por la asamblea legislativa francesa, como consecuencia de las protestas de Haití. Al mismo tiempo, los representantes diplomáticos dominicanos habían entrado en negociaciones con Gran Bretaña, que les presentó en noviembre de 
ese año un proyecto de tratado, el cual tampoco pudo firmarse, pero en este caso la razón se debió a un desacuerdo puntual que los comisionados habían de consultar con su gobierno. A pesar de dicho escollo, Robert Schomburgk fue nombrado cónsul de Gran Bretaña en Santo Domingo, ciudad donde ya se encontraban destinados el cónsul de Francia, Victor Place, y el agente comercial de Estados Unidos, quien desde agosto de 1848 era Jonathan Elliot.

\section{INJERENCIA EXTRANJERA EN LA POLÍTICA DOMINICANA}

Pedro Santana tomó posesión de la presidencia de la República, por segunda vez, el 15 de febrero de 1853, después de haber prestado el juramento constitucional ante el Congreso, y en presencia del presidente saliente, Buenaventura Báez. Este relevo pacífico en el poder se hizo según las prescripciones de la carta fundamental, a pesar de las difíciles circunstancias derivadas del enfrentamiento cada vez más duro entre los dos principales actores de aquella coyuntura política, esto es, el expresidente Báez y el propio general Santana. No obstante, los planteamientos de uno y otro eran muy similares, puesto que la ya crónica situación de inestabilidad política interna y la latente amenaza que suponía la actitud agresiva de Haití para la supervivencia de la República Dominicana llevaron a ambos mandatarios a buscar apoyos en los gobiernos de otros países, particularmente España, Francia, Gran Bretaña y Estados Unidos, de lo cual se derivó una injerencia externa permanente en casi todos sus asuntos.

Así, incluso antes de la independencia dominicana, en 1843 comenzaron a realizarse gestiones con España a través del capitán general de Cuba, y ya en 1844, inmediatamente después de la proclamación de la República, por medio del gobernador de Puerto Rico. Durante años el ejecutivo de Madrid vaciló "sobre el camino a seguir", pese a que "cobró cierto interés por la cuestión" en algunas ocasiones, como cuando el primer ministro francés François Guizot, "quien prefería no intervenir directamente en el contencioso" dominico-haitiano, animó a las autoridades españolas a defender "a su costa los intereses franceses en la zona". Francia "accedería al protectorado español” y se opondría a que "cualquier otra potencia adquiriese supremacía sobre la isla", en lo cual Inglaterra estaba conforme, aunque nada llegó a hacerse al respecto. A continuación, "viendo que España no se decidía”, Santana envió a José María Caminero 
en 1845 a Washington para negociar un tratado de reconocimiento con Estados Unidos, pero esas gestiones tampoco prosperaron ${ }^{2}$.

El siguiente intento consistió en la "primera misión negociadora oficial”, enviada a Madrid en septiembre de 1846, presidida por Báez, cuyo objetivo era que España, Francia y Gran Bretaña "reconociesen la independencia dominicana", a cambio de la firma de sendos tratados de amistad, comercio y navegación. Sin embargo, tras quince meses la comisión Báez abandonó Madrid sin haber obtenido éxito alguno, puesto que no se llegó a abrir la negociación, "ni se tomaron en consideración sus proposiciones". El propio Prim, durante su mandato en Puerto Rico (1847-1848), señaló a Narváez la conveniencia de anexionarse la parte oriental de la Española, para lo que adujo "la inestabilidad interna reinante" en la República Dominicana y "la perspectiva de reforzar estratégicamente" las posesiones españolas en el Caribe. Poco después de la subida de Báez a la presidencia, las tentativas se orientaron a Francia, que declinó la oferta de protectorado de aquel, por lo que el presidente se vio forzado a "dirigir sus requerimientos" hacia Washington. Al mismo tiempo confió al sacerdote Elías Rodríguez el encargo de ir a La Habana, junto con el comerciante español Juan Abril, para exponer al gobernador de Cuba "los peligros que entrañaría una presencia" estadounidense estable en la República Dominicana. De hecho, en el discurso que pronunció en febrero de 1853 para rendir cuentas de su gestión ante el Congreso, Báez "se refirió a los peligros que amenazaban la soberanía española en Cuba" y manifestó "la conveniencia de estrechar relaciones con España"3.

Juan Abril, que actuaba como agente confidencial en Santo Domingo, comunicó a Valentín Cañedo, capitán general de Cuba, la formación del nuevo gobierno dominicano y le informó de las gestiones realizadas por él, de acuerdo con el cónsul francés en aquella ciudad, para impedir la inclusión de Delmonte en el ejecutivo, debido a sus simpatías hacia Estados Unidos. El mencionado agente explicó su actuación en estos términos: "Yo doy toda esta importancia al ministerio por si nuestro gobierno no se decide pronto a entrar en alguna combinación y es preciso o necesario mantener una influencia en los destinos de este país". En otro orden de cosas, Abril refirió al

\footnotetext{
${ }^{2}$ Eduardo González Calleja y Antonio Fontecha Pedraza, Una cuestión de honor. La polémica sobre la anexión de Santo Domingo vista desde España (1861-1865) (Santo Domingo: Fundación García Arévalo, 2005), 22-24.

${ }^{3}$ González y Fontecha, Una cuestión de honor..., 24-25.
} 
gobernador el contenido de una carta confidencial de Maxime Raybaud, cónsul de Francia en Puerto Príncipe, donde este indicaba que Gran Bretaña quería "desistir de la mediación" que venía desarrollando junto a Francia para facilitar el entendimiento pacífico entre los dos países de la isla. Como es lógico, dicha posibilidad hizo que Santana se preocupara, más aún tras conocerse la noticia de que Faustin Soulouque, presidente de Haití, estaba preparando sus tropas para una nueva invasión del territorio dominicano ${ }^{4}$.

Efectivamente, la actitud del gobierno británico parecía estar cambiando y así se lo transmitió el propio Santana a Cañedo en marzo de 1853. El gobernador de Cuba comunicó el contenido de la carta de Santana al conde de Alcoy, quien el 14 de abril abandonó la jefatura del gobierno español, en la cual fue sustituido por el general Lersundi, que se mantuvo en dicho cargo hasta septiembre de ese año. Cañedo señaló los recelos de Santana ante "una próxima agresión por parte de los haitianos", y "su escasa confianza en la mediación de Inglaterra y Francia para impedirlo". Cañedo añadió que, según le había informado Abril, la sinceridad de la primera en sus ofertas de continuar mediando era "más que dudosa para el gobierno dominicano" y que, a falta de otro apoyo o mediación para prevenir las agresiones de Haití, los dominicanos se verían obligados a buscarlos en cualquier otra nación, incluida Estados Unidos, "por mucho que detestasen el filibusterismo". Santana también se dirigió ese mismo mes al gobernador de Puerto Rico, a fin de pedirle su ayuda en caso de que un ataque por parte de Soulouque rompiera la frágil tregua existente entre la República Dominicana y Haití, lo cual no se produjo hasta finales de 1855.

Pese a los temores que habían expresado tanto Santana como Raybaud acerca de la continuidad de la mediación franco-británica, este último viajó a Santo Domingo con el objetivo de confirmar al presidente "las garantías ofrecidas a la República por las potencias mediatrices [sic], garantías representadas por las letras patentes" que la reina Victoria de Inglaterra había firmado el 13 de mayo, y el 28 del mismo mes el emperador de Francia. En ellas, ambos monarcas aseguraron a Santana que "su deseo era mantener

\footnotetext{
${ }^{4}$ Carta de Juan Abril al capitán general de Cuba, Santo Domingo, 22 de febrero de 1853 (es copia). Archivo Histórico Nacional, Madrid (AHN), sección Ultramar, Santo Domingo, legajo 3524, documento n. ${ }^{\circ} 68$.

${ }^{5}$ Carta de Cañedo al presidente del Consejo de Ministros, La Habana, 8 de abril de 1853. Archivo del Ministerio de Asuntos Exteriores, Unión Europea y Cooperación, Madrid (AMAE), fondo Política, subfondo Política Exterior, serie República Dominicana, legajo H 2373.
} 
la independencia y prosperidad" de la República Dominicana, y que por tal razón “estaban dispuestos a hacer los mayores esfuerzos para impedir la continuación de las agresiones haitianas"6. Noticias tan halagüeñas como estas no pudieron menos de tranquilizar en gran medida a Santana y su gobierno, al verse de alguna manera protegidos frente a la amenaza de una nueva invasión por parte de Haití.

\section{Un nuevo intento dominicano por obtener el reconocimiento diplomático o la ayuda de España}

El presidente Santana, decidido a lanzar una ofensiva diplomática en varios países europeos con los que se pretendía establecer relaciones o mejorar las ya existentes, envió a Francia a su ministro de Relaciones Exteriores, con la misión de recuperar un clima de normalidad en las relaciones entre ambos gobiernos. Estas se encontraban algo enturbiadas como consecuencia de un incidente que había provocado la expulsión de dos súbditos franceses, acusados de realizar labores de espionaje a favor de Haití. El 15 de noviembre de 1853 Santana nombró a Delmonte representante del gobierno dominicano para firmar un tratado con Holanda, lo cual se llevó a cabo en la isla de Curazao, cuyo gobernador actuaba en representación de dicho país.

El 10 de diciembre del mismo año Santana nombró al general Mella agente confidencial con poder de negociación y lo destinó a España, donde debería "anudar los intereses de uno y otro país, en la persuasión de que logrado ese objeto quedaría asegurada la tranquilidad y el porvenir de los dominicanos" ${ }^{\prime 7}$, según expresó en esa fecha el ministro dominicano de Relaciones Exteriores a su homólogo español. Finalmente, otro comisionado fue encargado de la conclusión de un tratado similar a los anteriores con el reino de Cerdeña. Santana solicitó al gobernador de Puerto Rico que recomendase a Mella ante el gobierno español, después de explicarle la misión que el general debía desempeñar en España:

El deseo [...] de evitar que extrañas influencias puedan amenazar la estabilidad de las cosas me han obligado a enviar al general Mella [...] cerca del gobierno de S. M. C. con el objeto de

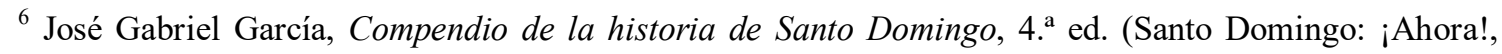
1968), tomo 3: 115-116.

${ }^{7}$ García, Compendio de la historia..., tomo 3: 117.
} 
manifestarle [...] mi entera disposición a adoptar un medio eficaz que garantice la seguridad de esta isla [...]. Creo que V. E. tomará un interés por esta población que se halla ligada a la suerte de esa isla y la de Cuba, por la misma religión, usos, costumbres y especialmente por su situación geográfica. ${ }^{8}$

En su respuesta a Santana, Norzagaray le transmitió una opinión favorable acerca de la acogida que la misión de Mella recibiría por parte del gobierno español, al tiempo que aceptaba su solicitud de recomendación. El gobernador se aventuró incluso a asegurarle que "si llegara la hora del peligro para la República Dominicana", viniese este de donde viniese, España no la dejaría "abandonada a sus propias fuerzas"". En una de las cartas que proporcionó a Mella para que le sirvieran de introducción a su llegada, dirigida al general Caballero, Norzagaray expresó más abiertamente su pensamiento con relación a las proposiciones que el comisionado dominicano tenía orden de plantear al gobierno español:

No estando como no está reconocida por nosotros la República Dominicana, [...] no me parece que es aceptable la pretensión de su actual gobierno sin previo reconocimiento de su independencia, ni aun supuesto, creo que nos reportaría provecho alguno el protectorado y sí muchos inconvenientes respecto de las demás naciones; y también juzgo que mayores nos los acarrease el dominar otra vez ese territorio [...]; pero si una y otra cosa no nos traerían beneficio alguno, también creo que sería un grave mal para [...] Cuba y Puerto Rico el que Haití reconquistase a su vecina república de Santo Domingo, o que los norteamericanos se posesionasen de ella, sea en el concepto de anexión, de protectorado o de cualquier otro. Por eso [...] apoyo las pretensiones del gobierno dominicano de que se le sostenga y garantice la estabilidad de su república, no en el concepto de que España se declare su protectora, sino en el de que las naciones que poseen colonias en este archipiélago se confederen [...] en el sentido de que subsista firme el estado de cosas en la inmediata isla de Santo Domingo ${ }^{10}$.

Ángel Calderón de la Barca, quien había sido durante muchos años embajador de España en Washington, y por tanto estaba al corriente de la cuestión dominicana, fue

\footnotetext{
${ }^{8}$ Carta de Santana a Norzagaray, Santo Domingo, 10 de diciembre de 1853 (es copia). AMAE, fondo Política, subfondo Política Exterior, serie República Dominicana, legajo H 2373.

${ }^{9}$ Carta de Norzagaray a Santana, San Juan de Puerto Rico, 16 de diciembre de 1853 (es copia). AMAE, fondo Política, subfondo Política Exterior, serie República Dominicana, legajo H 2373.

${ }^{10}$ Carta de Norzagaray a Caballero, San Juan de Puerto Rico, 21 de diciembre de 1853. AMAE, fondo Política, subfondo Política Exterior, serie República Dominicana, legajo H 2373.
} 
nombrado ministro de Estado cuando se constituyó el gabinete Sartorius. El 18 de febrero de 1854 Mella y Calderón mantuvieron una primera entrevista, en la cual el enviado de Santana le propuso las dos opciones que su gobierno consideraba más convenientes: el protectorado o el reconocimiento de la independencia por parte de España. Antes de dar por terminado su encuentro, Mella insistió en que Santana deseaba evitar la tesitura de tener que aceptar cualquier otro amparo por pura necesidad.

Después de la segunda entrevista entre ambos, el 13 de marzo, Calderón redactó un informe sobre la misión de Mella, destinado al presidente del Consejo de Ministros. En él afirmó que tenía por seguro que Estados Unidos se opondría al protectorado de España en Santo Domingo, "muy especialmente el partido democrático", que se encontraba al frente del ejecutivo de Washington y era un firme defensor de la "máxima política conocida en aquel país por el nombre de the Monroe Doctrine". El ministro de Estado también previó que dicha oposición llevaría aparejada la del gobierno británico, debido a su política "temerosa siempre de provocar conflictos" con los norteamericanos. Por lo que respecta a Francia, advirtió de la influencia que tendrían "sus relaciones con el imperio de Haití, en la manera como considerase la cuestión del protectorado" español en la otra parte de la isla. Finalmente, Calderón resumió su exposición en los siguientes puntos:

1. ${ }^{\circ}$ Que la España no puede conceder el protectorado material a la República Dominicana, por la dificultad de ejercerlo y por los gastos y los seguros compromisos que le originaría.

2. ${ }^{\circ}$ Que sería prematuro y sin compensaciones el reconocimiento de la independencia de dicha República.

3. ${ }^{\circ}$ Que es importantísimo y urgente evitar que esta sea conquistada por los negros de Haití, o se arroje en brazos de los filibusteros americanos.

$4{ }^{\circ}$ Que convendría tratar de esto, y concertar el remedio [...] con las potencias amigas que tienen posesiones en Ultramar.

Y 5. ${ }^{\circ}$ Que por ahora, sin destruir ni alentar las esperanzas del comisionado general Mella en cuanto al reconocimiento de la independencia, podría enviarse a Santo Domingo un agente oficioso que informase a este ministerio [...] acerca de la situación de la República ${ }^{11}$.

\footnotetext{
${ }^{11}$ Carta de Calderón de la Barca a Sartorius, Madrid, 16 de marzo de 1854. AHN, sección Ultramar, Santo Domingo, legajo 3524, documento n. ${ }^{\circ} 72$.
} 
Las opiniones de Norzagaray y del ministro de Estado eran bastante similares, pues ambas coincidían en señalar que el objetivo fundamental de la diplomacia española en las Antillas era la preservación de la independencia de la República Dominicana. No obstante, la premisa básica que guiaba esa política era mantener siempre la mirada puesta en encontrar la mejor solución posible para proteger Cuba y Puerto Rico frente a las tendencias expansionistas de Estados Unidos, así como la necesidad de actuar por medio de un acuerdo con Francia y Gran Bretaña, fundamentalmente.

Calderón dirigió en abril de 1854 una comunicación a los embajadores de España en París y Londres, donde les informó de las gestiones que Mella estaba llevando a cabo en Madrid por encargo de su gobierno. El ministro les hizo ver la conveniencia de precaver en la medida de lo posible el inminente riesgo que corría la República Dominicana, si las potencias europeas no acudían en su auxilio, tanto de ser invadida por Haití como de caer en poder de Estados Unidos, cuyo gobierno pretendía hacerse con la bahía de Samaná. Ante esa doble amenaza, Mella hablaba "sin rebozo de la resolución de su gobierno de implorar la protección de los Estados Unidos más bien que ser presa del emperador de Haití", por lo que España consideraba necesario que las dos grandes naciones europeas evitasen tal eventualidad. En sus instrucciones, Calderón solicitó a ambos diplomáticos que le informaran de la postura de los gobiernos francés y británico sobre este asunto, pues el español deseaba proceder en el mismo de acuerdo con aquellos ${ }^{12}$.

En primer lugar, el representante de España en Londres respondió que el conde de Clarendon, quien se encontraba al frente del Foreign Office, le había manifestado que su gobierno no vería con indiferencia que Estados Unidos se apoderase de Samaná, y que encontraba muy acertado que el gobierno español se hubiera abstenido de conceder un protectorado que lo habría envuelto en compromisos y dispendios ${ }^{13}$.

Por su parte, el marqués de Viluma, embajador de España en París, en respuesta a la carta que había recibido de Mella, le comunicó que el ministro francés del Exterior, Drouyn de L’Huys, había dado muestras del vivo interés que Francia tenía en la libre existencia de la República Dominicana. En la conversación que ambos mantuvieron, el

\footnotetext{
${ }^{12}$ Carta del ministro de Estado al embajador de España en París, Madrid, 7 de abril de 1854 (minuta); Carta del ministro de Estado al encargado de negocios de España en Londres, Madrid, 7 de abril de 1854 (minuta). AMAE, fondo Política, subfondo Política Exterior, serie República Dominicana, legajo H 2373.

${ }^{13}$ Carta del embajador de España en Londres al ministro de Estado, Londres, 22 de abril de 1854. AMAE, fondo Política, subfondo Política Exterior, serie República Dominicana, legajo H 2373.
} 
ministro afirmó que "no estaba la República Dominicana abandonada de la protección de las potencias marítimas", y le aseguró que ni Francia ni Gran Bretaña permitirían que la República Dominicana aumentase los dominios de Estados Unidos, así como que ninguna de las dos pretendía "ninguna nueva adquisición". Viluma concluyó indicando que tan solo España tenía derecho a reincorporar el territorio dominicano a sus dominios, pero que las circunstancias en que ella se encontraba podrían prolongar quizá "el momento de una terminación satisfactoria a la situación actual". En cualquier caso, el embajador de España en París dejó claro a Mella que "el gobierno de S. M. Católica" era "el único" al cual podía "dirigirse sobre este particular"14.

Tal como hacían prever las palabras del embajador, la respuesta del gobierno español a las sucesivas demandas de Mella fue siempre la misma negativa a dar un paso decisivo, manifestando las simpatías de España hacia Santo Domingo, pero eludiendo "acceder al reconocimiento solicitado". En su último intento por alcanzar algún acuerdo el comisionado dominicano, en vista de que el ministro seguía rechazando tanto la opción del protectorado, solicitada en primer lugar, como la del mero reconocimiento diplomático, propuso a Calderón que el gobierno español se limitara al nombramiento de sendos agentes consulares o comerciales en Santo Domingo y Puerto Príncipe. Esta medida no implicaba el reconocimiento formal de ninguno de los dos gobiernos de la isla, según la práctica ya establecida por otros países, como Francia o Estados Unidos, pero tampoco fue aceptada por el ministro de Estado, quien juzgaba "preferible que los referidos agentes fuesen sin carácter público" $" 15$.

Mella concluyó su misión en España tras dirigirse de nuevo al ministro de Estado por medio de una carta en que hizo referencia a su memorándum del 23 de marzo, donde había sometido a su consideración el hecho de que "la necesidad imperiosa de la propia conservación podía obligar a la República Dominicana a tratar con otras naciones bajo la base de mutua conveniencia y provecho". Por último, Mella lanzó una velada advertencia al llamar la atención del ministro sobre la posibilidad de que, incluso aunque tales tratos no se hicieran en agravio ni perjuicio de los intereses de

\footnotetext{
${ }^{14}$ Carta del marqués de Viluma al general Mella, París, 29 de abril de 1854 (el documento consultado es una copia enviada por Viluma, embajador de España en París, al ministro de Estado). AMAE, fondo Política, subfondo Política Exterior, serie República Dominicana, legajo H 2373.

${ }^{15}$ Carta de Calderón de la Barca a Sartorius, Madrid, 12 de mayo de 1854. AHN, sección Ultramar, Santo Domingo, legajo 3524, documento n. ${ }^{\circ} 74$.
} 
España, bastaría que se hiciesen sin su anuencia para conllevar la contingencia de que algún día pudieran serle hostiles ${ }^{16}$.

Antes de abandonar la capital, Mella dejó encargado de la continuación del negocio a Rafael María Baralt, escritor de origen venezolano y madre dominicana residente en España y nacionalizado español, después de lo cual partió con destino a Puerto Rico a finales de mayo. Una vez en Santo Domingo, Mella presentó al ministro de Relaciones Exteriores dominicano un informe sobre el resultado de sus gestiones en Madrid, donde le expuso lo siguiente:

1. ${ }^{\circ}$ que España desea vivamente que la República exista y prospere separada del poder de Haití, como nación libre e independiente de toda dominación extranjera; $2{ }^{\circ}$, que por el momento no le es posible ni siquiera ocuparse seriamente en el reconocimiento de la independencia; 3. ${ }^{\circ}$, que no desatiende tanto, sin embargo, la suerte del pueblo dominicano que deje de mirarlo en sus relaciones internacionales como el amigo y aliado más natural que tiene en las Antillas [...]; 4. ${ }^{\circ}$ y finalmente, que la negociación lejos de haber quedado rota está aún pendiente, esperando momentos más sosegados y oportunos $^{17}$.

\section{Principales características de la política exterior española a mediados del siglo XIX}

La actitud del gobierno español se había visto determinada en gran medida por la difícil situación interna que atravesaba el país en aquellos momentos, sobre todo como consecuencia de las revueltas y disturbios que se estaban produciendo en diferentes ciudades, como consecuencia de una fallida sublevación contra el gobierno en Zaragoza en febrero de 1854. Estos problemas no eran, sin embargo, los únicos que acaparaban la atención preferente del gobierno y de la opinión pública en España, ya que también siguieron produciéndose roces en sus relaciones con Estados Unidos, como el incidente del Black Warrior, un barco acusado de contrabando que fue apresado por las autoridades españolas en Cuba y posteriormente liberado, debido a las protestas del

\footnotetext{
16 Carlos Federico Pérez, Historia diplomática de Santo Domingo 1492-1861 (Santo Domingo: Universidad Nacional Pedro Henríquez Ureña, 1973), 274-275.

${ }^{17}$ Amadeo Julián, "La situación internacional, la crisis económica nacional y la misión Mella a España en 1854", en La sociedad dominicana durante la Primera República 1844-1861, ed. por Tirso Mejía-Ricart G. (Santo Domingo: Universidad Autónoma de Santo Domingo, 1977), 304-305. El autor cita el Informe de Mella al ministro de Relaciones Exteriores de la República Dominicana, Santo Domingo, 22 de agosto de 1854.
} 
gobierno norteamericano. El embajador de Estados Unidos en Madrid, Pierre Soulé, tenía instrucciones de William L. Marcy, secretario de Estado norteamericano, de proponer al gobierno español la venta de Cuba, oferta que por supuesto fue rechazada.

En cualquier caso, la situación de la República Dominicana no parecía tan desesperada como para tener que adoptar una resolución inmediata, que podría resultar embarazosa a causa de las reacciones hostiles de algunos actores del juego antillano, como los esclavistas cubanos o los independentistas y anexionistas de esa isla, sumadas a las reticencias e incluso la abierta oposición que probablemente despertaría en las distintas naciones con intereses en la zona, como Estados Unidos o las potencias europeas, sin olvidar a Haití.

Pocos meses después, la política española hacia la República Dominicana experimentó un giro de ciento ochenta grados, no solo por efecto de la llegada al poder de los progresistas tras los hechos revolucionarios del verano de 1854. La explicación hay que buscarla más bien en un proyecto de tratado entre Estados Unidos y la República Dominicana que contemplaba, como condición indispensable por parte del primero, el arrendamiento de un terreno en la bahía de Samaná por tiempo indefinido a cambio de una pequeña renta anual, con el supuesto objetivo de establecer allí un depósito de carbón para abastecer a sus buques.

En cualquier caso, resulta indiscutible que hacia 1856-1858, e incluso desde que en 1854 el doctrinario puritano Joaquín Francisco Pacheco y el general O’Donnell ocuparon las carteras de Estado y Guerra, respectivamente, en niveles administrativos del Ministerio de Estado, afines a la recién creada Unión Liberal, se propugnaba "una política de prestigio". Esta se basaba en impulsar "una fuerza naval que respaldase las negociaciones a la sazón celebradas entre España y determinadas repúblicas iberoamericanas". Efectivamente, según Jover Zamora, en este aspecto también cabe establecer una distinción entre los progresistas, partidarios de "una política realista" respecto a dichos países, por medio de "un fomento de las relaciones comerciales", y los moderados, pero muy "en particular los unionistas", que se decantaban por construir una escuadra importante. Esta debería testimoniar ante las naciones hispanoamericanas "el 
poderío de la antigua metrópoli”, lo cual también serviría indirectamente para fortalecer de cara a ellas "la posición de España en los últimos reductos" de su imperio ${ }^{18}$.

No obstante, las causas de “la reiterada 'vocación' exterior del gobierno unionista" han sido banalizadas con frecuencia, pues numerosos autores, extremando la interpretación de Jover, consideran que todas sus intervenciones coloniales y militares estaban "supeditadas al expansionismo de otras potencias europeas", principalmente Francia. Martínez Gallego señala que la causalidad de dicha actuación "suele reducirse a motivaciones de prestigio, de consolidación de un nacionalismo interno ganado a fuerza de contraste con el exterior, de desviacionismo de los problemas internos, de forma de promoción del estamento militar, de hálito romántico y hasta de calaverada". Sin embargo, es indudable que la política exterior española durante esta etapa tuvo como prioridad "la salvaguarda de sus posesiones coloniales" y de la esclavitud, "la "particular institución' que hacía funcionar el sector dominante de la economía cubana". Dicho autor concluye que Santo Domingo, como los demás "hitos coloniales o bélicos" de la etapa de gobierno de la Unión Liberal, había sido "una parte de la malla de protección" trenzada para proteger las colonias antillanas, de modo que, si a estas "se las denominaba perlas", la política exterior unionista debería ser vista como "su concha"19.

Por su parte, Inarejos Muñoz señala que "las progresivas dificultades impuestas al tráfico de esclavos y la propia dinámica de la metrópoli y sus colonias, mediatizadas por la inestabilidad peninsular y el estallido de levantamientos en Cuba, resultaron decisivas" en el diseño y la aplicación de la política desplegada por los gobiernos de la Unión Liberal. El mencionado autor califica de "tópicos" las acusaciones de “incoherencia y falta de objetivos" vertidas por la historiografía clásica sobre ese periodo contra las diversas intervenciones unionistas en el exterior, y considera que se trata de "prejuicios en gran medida derivados de la falta de un análisis de conjunto" de cada campaña, así como de las relaciones existentes entre ellas. Inarejos también indica que "precisamente esta interconexión entre campañas se erigió en una constante en las intervenciones exteriores de la Unión Liberal", y sus críticas se centran en quienes, como Jover, insisten en "la supuesta esterilidad, incoherencia y romanticismo de la

\footnotetext{
${ }^{18}$ José María Jover Zamora, La civilización española a mediados del siglo XIX (Madrid: Espasa-Calpe, 1992), 279-280.

${ }^{19}$ Francesc Andreu Martínez Gallego, Conservar progresando: la Unión Liberal (1856-1868) (Valencia: Centro Francisco Tomás y Valiente UNED Alzira-Valencia; Fundación Instituto de Historia Social, 2001), 117 y $154-156$.
} 
política exterior unionista". Dicho autor se muestra asimismo en desacuerdo con Álvarez Junco, cuya obra "profundiza en algunos de los lugares comunes ya señalados", al estudiar "el intento de expansión imperial y el fracaso que supuso no obtener ganancias territoriales". A juicio de Inarejos, en cambio, "un análisis detenido de la política exterior o'donnellista ratifica que la prioridad era la conservación de las posesiones existentes". En cuanto a "los móviles que dirigieron sus intervenciones exteriores", Álvarez Junco afirma que España actuó “movida solo por la defensa del 'honor' nacional -a diferencia de otras potencias que perseguían intereses materiales"20. En definitiva, la política exterior y colonial de la Unión Liberal no reparó en gastos a la hora de intervenir en el Pacífico o en las inmediaciones de los territorios amenazados del Caribe. Contemplada la cuestión desde este punto de vista, quizá ya no resulte tan fácil referirse simplemente a una política de prestigio, sin mayores matices.

\section{PRESIONES EUROPEAS DURANTE LA NEGOCIACIÓN DEL PRIMER PROYECTO DE TRATADO DOMINICO-ESTADOUNIDENSE EN 1854}

Jonathan Elliott, agente comercial de Estados Unidos en Santo Domingo, dirigió una comunicación a sus superiores en diciembre de 1853 donde ya previó que si las gestiones de Mella en España fracasaban, algo que juzgaba lo más probable, el ejecutivo y el pueblo dominicanos solicitarían la protección de Estados Unidos. El gobierno norteamericano no perdió el tiempo, y el secretario de Estado Marcy envió al general Cazneau a la República Dominicana en enero de 1854, con el encargo de averiguar tanto las condiciones en que se encontraba el país como la actitud de su gobierno respecto a la firma de un tratado entre ambas naciones. Las autoridades norteamericanas eligieron para el desempeño de tales funciones seudodiplomáticas a un individuo de turbia trayectoria, vinculada a la anexión de Tejas a Estados Unidos.

Dentro del gabinete Pierce, el secretario Marcy puede considerarse el principal defensor de la doctrina del destino manifiesto, que como es bien sabido defiende la expansión territorial estadounidense hacia el sur, "especialmente en dirección a las

\footnotetext{
${ }^{20}$ Juan Antonio Inarejos Muñoz, Intervenciones coloniales y nacionalismo español. La política exterior de la Unión Liberal y sus vínculos con la Francia de Napoleón III (1856-1868) (Madrid: Sílex, 2010), 62. Inarejos cita a José Álvarez Junco, Mater Dolorosa. La idea de España en el siglo XIX (Madrid: Taurus, 2001), 516-517.
} 
Antillas". Por lo tanto, Marcy "se persuadió fácilmente de las ventajas que ofrecía la anexión de Santo Domingo" ${ }^{21}$ y convenció de ello también al presidente Pierce. La oportunidad que se les presentaba para llevar a cabo este plan era inmejorable, teniendo en cuenta la situación en Europa debido a la guerra de Crimea, donde Gran Bretaña y Francia estaban a punto de implicarse militarmente.

Cazneau pudo comprobar sin tardanza que el gobierno dominicano estaba muy interesado en estrechar sus vínculos con el de Estados Unidos por medio de un tratado de reconocimiento diplomático. En efecto, hasta ese momento el ejecutivo de Santana se había visto obligado a "depender de la buena voluntad de Francia e Inglaterra para disfrutar del alivio transitorio de la tregua existente con Haití", tal como Cazneau escribió a Marcy poco después de su llegada a Santo Domingo. En otra parte de su comunicación aquel afirmó que "carecía de importancia” la misión de Mella en Madrid, aunque la opinión generalizada era que el objetivo de la misma consistía en negociar "la vuelta de la República Dominicana a la sumisión de la monarquía española”. Según sus conclusiones, "la idea predominante en la política" de Santana era poner el país "preferentemente bajo la protección de Estados Unidos"22.

Junto con su nombramiento como agente especial, Cazneau había recibido los poderes necesarios para comenzar la negociación de un tratado con el gobierno dominicano, y tras cumplir dicho encargo regresó a Washington para presentárselo a Marcy. Este introdujo una nueva cláusula en el proyecto, que acabó convirtiéndose en su verdadera razón de ser, consistente en el arrendamiento de una milla cuadrada de terreno en Samaná destinada a la construcción de una estación carbonera para uso de los buques de guerra norteamericanos. Era tanta la importancia concedida por el secretario de Estado a ese punto que, en sus nuevas instrucciones a Cazneau, Marcy indicó que si el tratado no era aceptado íntegramente el Senado de Estados Unidos tampoco lo aprobaría, en el caso dudoso de que el ejecutivo de Washington llegase a someterlo a ratificación.

En un informe de la Dirección General de Ultramar de noviembre de 1854, se dio cuenta de la carta enviada por el gobernador de Puerto Rico el 1 de julio, donde este advirtió que, según noticias recibidas del agente español en Santo Domingo:

\footnotetext{
${ }^{21}$ Sumner Welles, La viña de Naboth. La República Dominicana 1844-1924, 4. a ed. (Santo Domingo: Taller, 1981), vol. 1: 138-141.

${ }^{22}$ Welles, La viña de Naboth..., vol. 1: 145.
} 
El general americano Cazneau se hallaba nuevamente en dicha isla, y si bien hasta entonces ninguna proposición habría presentado al presidente ni a su gobierno, se suponía con algún fundamento que su regreso tenía por objeto proponer una inmigración de americanos por la península de Samaná [...], a lo cual no se accedería por el jefe actual de la república, mientras no tenga contestación de las proposiciones que por medio de su enviado tiene hechas a nuestro gobierno [...]; pero que si se atiende a lo poco satisfecho que del resultado de su comisión viene [...] Mella, no sería de extrañar que Cazneau consiguiera en aquellos momentos [...] sus miras de anexión de la isla de Santo Domingo a la Unión americana, en cuyo caso nuestra posición sería muy crítica y no sería fácil prevenir las consecuencias que con el tiempo pudieran sobrevenir por su proximidad, no favoreciendo nada a nuestros intereses cualquier tratado que se ajustara entre ambos ${ }^{23}$.

La recomendación final de Norzagaray, tal como se recoge en el mismo informe, fue que, antes de desahuciarse completamente las propuestas planteadas por Mella, debía "tenerse todo en cuenta para dictar una resolución" que permitiera afianzar la paz y la tranquilidad en Puerto Rico y Cuba. Las informaciones que el agente Abril hizo llegar al gobernador de Puerto Rico no dejaban lugar a dudas sobre las intenciones del comisionado norteamericano ${ }^{24}$.

Así, en otra comunicación que dirigió el 31 de julio de 1854 al presidente del Consejo de Ministros, Norzagaray insistió en la necesidad de rectificar la postura del gobierno español hacia la República Dominicana, El objetivo era impedir que esta, "a pesar de sus simpatías y del interés manifestado hasta ahora", ante la imposibilidad de mantenerse como se hallaba, y necesitando otra nación más poderosa que la protegiese, buscara amparo en Estados Unidos, "ávidos de adquirir preponderancia y dominación en las Antillas". En caso de no actuar decididamente para evitar esa posibilidad, el gobernador advirtió de lo siguiente en tono un tanto dramático: "Tendremos, no solo nosotros, sino también las naciones de Europa que tienen aquí colonias, que sufrir las

\footnotetext{
${ }^{23}$ Informe de la Dirección General de Ultramar, Madrid, 3 de noviembre de 1854 (lleva al pie las firmas de Carralón y Enríquez). AHN, sección Ultramar, Santo Domingo, legajo 3524, documento n. ${ }^{\circ} 4$. (La Dirección General de Ultramar se creó por real decreto de 30 de septiembre de 1851, dependiente de la Presidencia del Consejo de Ministros, y se reorganizó en tres secciones: Justicia, Hacienda y Gobierno, por real decreto de 26 de enero de 1853. Véase Archivo Histórico Nacional (España), Papeles de Santo Domingo (Madrid: Dirección General de Bellas Artes y Archivos, 1985), 11-12.

${ }^{24}$ Ibidem.
} 
consecuencias de lo que hoy temen por la ambición de un estado poderoso que [...] aspira al dominio de todos estos países" 25 .

Los cónsules de Francia y Gran Bretaña recibieron instrucciones de oponerse por todos los medios a la firma de cualquier tratado que conllevara la cesión de una parte del territorio dominicano a Estados Unidos, a lo cual Santana ya había accedido, de modo que el 8 de septiembre de 1854 ambos cónsules amenazaron al presidente con retirarse de la mediación entre la República Dominicana y Haití. La presión diplomática fue muy intensa y contó con el apoyo más o menos simbólico de la llegada al puerto de Santo Domingo de un buque de guerra británico. En tales circunstancias Santana no tuvo más remedio que ceder a esas exigencias y suprimir la cláusula relativa a Samaná, pese a lo cual Cazneau y dos representantes del gobierno dominicano firmaron el tratado el 5 de octubre de 1854 .

No obstante, incluso tras la eliminación de esa cláusula, la firma del tratado implicaba un cierto riesgo de dejar a la República Dominicana desprotegida frente a Haití. Esto requiere una explicación que quizá resida en el deseo de Santana “de sobreponerse a la dependencia exclusiva de Francia e Inglaterra”, países que juzgaba partidarios de Báez, en lo cual no se equivocaba demasiado. Por esta razón, cabe interpretar el empeño de Santana como un intento de "crear un equilibrio en el exterior", que se habría "reflejado en su beneficio en la situación política de la República ${ }^{26}$, que en esos momentos no le era favorable. En efecto, la oposición al régimen de Santana mantenía una actividad cada vez mayor, tras suprimirse de la nueva constitución promulgada en febrero de 1854 el polémico artículo 210, lo cual había permitido ampliar el ejercicio de las libertades públicas.

\section{Reactivación de la injerencia europea en la República Dominicana}

Mientras tanto, el gobierno español se dispuso a tomar una parte mucho más activa en los asuntos dominicanos, y el primer paso que dio en tal dirección fue nombrar agente comercial en Santo Domingo a Eduardo San Just. El ministro de Estado, Joaquín Pacheco, indicó en las instrucciones que dio al nuevo agente que su encargo era "del

\footnotetext{
${ }^{25}$ Carta de Norzagaray al presidente del Consejo de Ministros, San Juan de Puerto Rico, 31 de julio de 1854. AHN, sección Ultramar, Santo Domingo, legajo 3524, documento n. ${ }^{\circ} 76$.

${ }^{26}$ Pérez, Historia diplomática..., 281-282.
} 
mayor interés para la conservación de Cuba", pues la situación geográfica de la República Dominicana haría muy peligroso que Estados Unidos se apoderase de ella. El objetivo principal de la misión encomendada a San Just era "valerse de todos los medios" posibles para obstaculizar los proyectos norteamericanos. A tal fin, debía "reanimar la esperanza" de Santana y su confianza en España, haciéndole entender que el ejecutivo de Madrid deseaba estrechar relaciones con el de Santo Domingo, de lo cual constituía buena prueba el envío de un agente comercial. El gobierno español fue más allá en sus muestras de interés por ganar la máxima influencia en la isla, y aseguró estar dispuesto a "reconocer la independencia" de la República Dominicana si esta quisiera enviar un agente a Madrid. Finalmente, Pacheco dio instrucciones a San Just de que procurase "utilizar la influencia de los agentes consulares de Francia e Inglaterra, interesados en poner coto a las invasiones de la Unión americana", para contrarrestar sus "planes ambiciosos",27.

La decisión de nombrar un agente comercial en Santo Domingo se adelantó a las noticias transmitidas por Cueto, embajador de España en Washington, quien informó de las intenciones que supuestamente guiaban los últimos movimientos de los norteamericanos en la República Dominicana. En una comunicación dirigida al ministro de Estado el 2 de septiembre de 1854, Cueto señaló lo siguiente:

El afán que una parte del Congreso y del pueblo están aquí manifestando [...] por establecer un apostadero en la citada bahía (de Samaná) y aun por convertir a la isla entera de Santo Domingo según la expresión de "The Tribune" de Nueva York, en un apéndice de la Unión, la situación geográfica de la isla entre Cuba y Puerto Rico; el haber enviado [...] un negociador; son consideraciones que el gobierno de S. M. no debe, en mi sentir, perder de vista ${ }^{28}$.

A la vista de estos hechos, el embajador recomendó "el nombramiento inmediato" de dos representantes con el carácter de meros agentes comerciales, que no implicaba reconocimiento alguno, en Puerto Príncipe y Santo Domingo. El objetivo era que estos "se asociasen a la obra de mediación" que ejercían Francia y Gran Bretaña entre los dos estados de la isla, "y vigilasen y entorpeciesen las gestiones" que hacía el

\footnotetext{
${ }^{27}$ Instrucciones del ministro de Estado al agente comercial de España en Santo Domingo, Madrid, 11 de septiembre de 1854. AHN, sección Ultramar, Santo Domingo, legajo 3524, documento n. ${ }^{\circ} 77$.

${ }^{28}$ Carta de Cueto a Pacheco, Washington, 2 de septiembre de 1854 (el documento consultado es un oficio de traslado del Ministerio de Estado a la Dirección General de Ultramar, del 7 de octubre de 1854). AHN, sección Ultramar, Santo Domingo, legajo 3524, documento n. ${ }^{\circ} 79$.
} 
ejecutivo de Washington "para asentar allí su influencia”. El embajador británico en Madrid, lord Howden, comunicó a Pacheco el 5 de octubre de 1854 la respuesta que había recibido del conde de Clarendon, secretario del Foreign Office, en el sentido sugerido por el propio Howden. Este le había recomendado que diera instrucciones al cónsul de Inglaterra en Santo Domingo para que, en unión con el agente que en breve debía enviar el gobierno español a aquella isla, procurase disuadir al ejecutivo dominicano de toda idea de permitir que se establecieran los norteamericanos en Samaná. El embajador de Gran Bretaña expresó también a Pacheco su temor de que el tratado entre la República Dominicana y Estados Unidos encubriese el objetivo de "facilitar el envío de numerosos emigrados de la confederación", e imitando el ejemplo de lo ocurrido en Tejas, hicieran "desaparecer la nacionalidad de los naturales del país"29.

Además de usar las armas de la diplomacia, el gobierno español parecía dispuesto a adoptar otras medidas más contundentes para tratar de impedir que la mencionada emigración llegase a producirse, tal como se deduce del despacho que José de la Concha, nuevo capitán general de Cuba, hizo llegar al ministro de Estado. En él, De la Concha le indicó que, con arreglo a las últimas órdenes recibidas por su antecesor, había dispuesto que dentro de pocos días saliera "un vapor de guerra con las instrucciones convenientes" en dirección a las costas dominicanas. El comandante de este iba con instrucciones de hacer entender a Santana la disposición en que se encontraba el gobierno español respecto a la posibilidad "de reconocer aquella República y estrechar sus relaciones con ella”, pero también debía informarle de que la ratificación del tratado con Estados Unidos para la cesión de una parte de Samaná lo haría imposible ${ }^{30}$.

En su comunicación al ministro de Estado el gobernador de Cuba adjuntó una copia de la carta remitida por Abril desde Santo Domingo el 7 de octubre de 1854, donde el agente español le dio la noticia de que el gobierno dominicano había "concluido y firmado el tratado con el plenipotenciario de la Unión, y cedido un pedazo de Samaná, por un número de años”. Abril escribió a continuación que el ejecutivo de

\footnotetext{
${ }^{29}$ Carta de Howden a Pacheco, Madrid, 5 de octubre de 1854 (el documento consultado es un oficio de traslado del Ministerio de Estado a la Dirección General de Ultramar, del 11 de octubre de 1854). AHN, sección Ultramar, Santo Domingo, legajo 3524, documento n. ${ }^{\circ} 80$.

${ }^{30}$ Carta de De la Concha a Pacheco, La Habana, 25 de octubre de 1854. AHN, sección Ultramar, Santo Domingo, legajo 3524, documento n. ${ }^{\circ} 81$.
} 
Santo Domingo había convocado la cámara legislativa para el 1 de noviembre, pero afirmó estar seguro de que no se reuniría. Ello sería "el pretexto para su disolución, cambio de ley fundamental, facultades extraordinarias al poder ejecutivo, es decir dictadura”, con lo cual se sancionaría ocultamente el tratado. Al final de su despacho Abril lanzó un velado reproche hacia los anteriores gobiernos españoles, lamentando su falta de iniciativa con estas palabras: "Tengo temor de que se ha descansado demasiado en el compromiso por las potencias de Europa en que sostendrían el statu quo de las Antillas". Y también criticó sutilmente al nuevo ejecutivo de Madrid, al afirmar acto seguido: "No puedo comprender cómo considera esta cuestión nuestro gobierno [...]; en los momentos en que más necesidad tengo de instrucciones, es cuando nada me dicen" 31 .

Aunque la cláusula relativa a la cesión de Samaná quedó finalmente excluida del tratado entre la República Dominicana y Estados Unidos, en contra de la información que había facilitado Abril, los representantes de Francia y Gran Bretaña no quedaron satisfechos, puesto que consideraban el tratado en sí mismo como una cuña para establecer algún tipo de control norteamericano sobre el país, con la complicidad de Santana. E1 27 de octubre de 1854 llegó a Santo Domingo Raybaud, cónsul de Francia en Puerto Príncipe, quien sondeó a Schomburgk acerca de la posibilidad de declarar un protectorado franco-británico en la República Dominicana, con el objetivo de volver a instalar a Báez en la presidencia.

Al final, su modo de actuar contra Santana y el tratado se centró en presionar a aquel para que lo sometiera a votación en el Senado Consultor, nombre oficial de la cámara legislativa dominicana, que había sido convocada por el presidente a fin de discutir la conveniencia de modificar la constitución aprobada a comienzos de ese mismo año. Los cónsules de Francia y Gran Bretaña en Santo Domingo, Darasse y Schomburgk, contaban con apoyos suficientes dentro del Senado que les permitirían la introducción de una serie de enmiendas en el tratado, de modo que lo hiciesen inaceptable para el gobierno de Estados Unidos.

En vista de la maniobra urdida por los diplomáticos de ambos países, y después de enviarles una carta donde los acusó de intromisión en los asuntos internos de la República Dominicana, el 23 de noviembre de 1854 Cazneau trató de retirar el tratado

\footnotetext{
${ }^{31}$ Ibidem.
} 
de la agenda del Senado. Sin embargo, ya era demasiado tarde para ello, porque una vez firmado solo existía la posibilidad legal de ser ratificado, modificado o rechazado por los legisladores de ambas naciones signatarias. Se constituyó una comisión encargada de informar a la cámara sobre el tratado, cuya dirección recayó en Teodoro Heneken, quien había actuado en ocasiones anteriores como agente oficioso del gobierno británico. Esta circunstancia, nada casual, hizo más sencilla la labor de los cónsules a la hora de conseguir que el Senado votara un texto diferente del original.

Así pues, a petición o más bien por exigencia de Schomburgk se realizó un cambio importante en el artículo tercero, estipulando que todos los ciudadanos dominicanos, "sin distinción de colores, gozarían en los Estados Unidos del mismo tratamiento que los ciudadanos americanos en Santo Domingo" ${ }^{\text {32 }}$. Tal modificación del tratado aseguraba la negativa norteamericana a ratificarlo, puesto que en el sur de Estados Unidos se encontraba vigente una legislación abiertamente discriminatoria por motivos raciales, además de existir un régimen legal de esclavitud.

A pesar de que el Senado acabó rechazando el tratado en la votación efectuada el 5 de diciembre de 1854, Schomburgk y Darasse fueron más allá. En efecto, el 14 de diciembre ambos cónsules exigieron al ejecutivo de Santo Domingo que aceptase una serie de condiciones a cambio de la continuación de su actividad mediadora ante Soulouque, a lo que aquel se negó, por medio de una nota del ministro de Relaciones Exteriores. La primera y principal de dichas condiciones era el compromiso, formal y por escrito, de no conceder privilegios a ninguna potencia extranjera frente a las demás, lo cual implicaba por supuesto no enajenar porción alguna del territorio dominicano a Estados Unidos.

Si bien el ejecutivo de Washington podría haber reaccionado, incluso con el uso de la fuerza, para oponerse a esta interferencia en sus relaciones con la República Dominicana, "tenía tal deseo de no enemistarse con Gran Bretaña" que, inmediatamente después de que Cazneau comunicara "el fracaso del tratado a causa de la oposición anglo-francesa”, le ordenó regresar. Por otra parte, lo único que Santana obtuvo de su "aventura" con Estados Unidos fue "ganarse la mala voluntad de Gran Bretaña y

\footnotetext{
${ }^{32}$ Welles, La viña de Naboth ..., vol. 1: 158.
} 
Francia"33, pudiendo concluirse que esta fue la "afirmación más cumplida de la influencia" y la presión diplomáticas de las potencias europeas en los asuntos de un estado americano. De hecho, la política de Francia y Gran Bretaña en el caso de Tejas, comparada con esta, resultó muy débil ${ }^{34}$.

\section{PASOS HACIA LA FIRMA DEL TRATADODE RECONOCIMIENTO DOMINICO-ESPAÑOL EN 1855}

Ante la noticia del nombramiento de San Just como agente comercial de España en la República Dominicana, el 31 de octubre de 1854 el gobernador de Puerto Rico se lamentó en una carta que remitió al ministro de Estado con estas palabras:

La pérdida que hemos de experimentar con la separación del actual agente secreto D. Juan Abril, puesto que con este solo carácter, pero valido de su posición, preponderancia y grande influencia en aquel pais [...] ha prestado por espacio de muchos años y está prestando servicios de la más grande importancia, [...] impidiendo antes y entreteniendo ahora como $V$. E. ha visto la realización de tratados que pueden ser perjudiciales a los intereses generales y a los particulares de España [...], estorbando la reunión del Congreso y contribuyendo por último a su disolución ${ }^{35}$.

Además, Norzagaray solicitó que el gobierno le concediese algún tipo de recompensa que le hiciera "menos sensible el no poder prestar ostensiblemente los propios servicios que reservados y gratuitamente" había prestado hasta entonces. Es lógico suponer que la actuación del agente español, coordinada con la de los cónsules británico y francés, había ejercido un influjo decisivo en el desarrollo de los acontecimientos que tuvieron lugar en Santo Domingo, "valiéndose para ello ya de sus muchas y elevadas relaciones entre los individuos del gobierno dominicano, ya haciendo

\footnotetext{
${ }^{33}$ Charles Christian Hauch, La República Dominicana y sus relaciones exteriores 1844-1882 (Santo Domingo: Sociedad Dominicana de Bibliófilos, 1996), 110.

34 Dexter Perkins, La cuestión de Santo Domingo 1849-1865 (Santo Domingo: Sociedad Dominicana de Bibliófilos, 1991), 19.

${ }^{35}$ Carta de Norzagaray a Pacheco, San Juan de Puerto Rico, 31 de octubre de 1854. AHN, sección Ultramar, Santo Domingo, legajo 3524, documento n. ${ }^{\circ} 83$.
} 
uso de la grandísima influencia e importancia" que tenía "con lo principal del país [...] por su ventajosa posición en él, y aun en el Congreso"36.

El papel desempeñado por España en esta crisis puede intuirse también a través de un despacho del gobernador de Cuba al ministro de Estado, donde afirmó haber conocido, gracias a las informaciones recibidas del embajador de España en Washington, que el gobierno español había tomado la iniciativa, siendo secundado por Inglaterra y Francia, "para evitar la ratificación del tratado" entre la República Dominicana y Estados Unidos. En su carta De la Concha comunicó asimismo la llegada a La Habana del nuevo agente comercial de España en Santo Domingo y que este, "considerando sumamente urgente su presencia en aquel puerto", había salido hacia allá sin demora, con escala en Puerto Príncipe, donde podría "ponerse de acuerdo con los cónsules de Francia e Inglaterra" que debían apoyarle en su misión según las instrucciones que tenían de sus gobiernos ${ }^{37}$.

El 24 de noviembre de 1854 San Just envió su primer despacho desde la capital dominicana al ministro de Estado, cargo que pasó a ocupar el 29 de noviembre Claudio Antón de Luzuriaga. En el acuse de recibo de este se recoge parte del contenido del mencionado despacho, según el cual San Just había recibido durante su breve estancia en Puerto Príncipe "el ofrecimiento de sincera cooperación por parte de los cónsules de Francia e Inglaterra". También el ministro de Relaciones Exteriores expresó a San Just las simpatías del gobierno haitiano hacia España, y le aseguró que tenía "el propósito de oponerse a la política del gabinete de Washington”. Luzuriaga transmitió al agente comercial español la aprobación de su conducta, al tiempo que le recomendó proceder siempre en términos que condujeran a establecer buenas relaciones entre España y los dos países que comparten la isla de Santo Domingo, así como "a crear obstáculos a las miras ambiciosas de la Unión americana" ${ }^{38}$.

La recepción que el gobierno haitiano dio a San Just no era tan solo la muestra de su deseo de mantener buenas relaciones con España, sino un medio para afianzar el frente de oposición a una intervención norteamericana en los asuntos de la isla. De

\footnotetext{
${ }^{36}$ Ibidem.

${ }^{37}$ Carta de De la Concha a Pacheco, La Habana, 12 de noviembre de 1854. AHN, sección Ultramar, Santo Domingo, legajo 3524, documento n. ${ }^{\circ} 84$.

${ }^{38}$ Carta de Luzuriaga a San Just, Madrid, 16 de enero de 1855. Archivo General de la Administración, Alcalá de Henares (AGA), sección Asuntos Exteriores, legajo 54/5224, carpeta n. ${ }^{\circ} 5$.
} 
hecho, durante el periodo en que se desarrolló la negociación entre Cazneau y las autoridades dominicanas, los cónsules francés y británico en Puerto Príncipe "no desperdiciaron oportunidad de impresionar la mente del emperador Faustino con el peligro que significaría para su propio dominio la ocupación de una parte de la isla por una nación esclavista" como Estados Unidos ${ }^{39}$.

En su segundo despacho al ministro de Estado, del mismo día que el primero, San Just dio cuenta de la entrega al presidente Santana de la carta que lo acreditaba como agente comercial de España en Santo Domingo, ciudad a la que había llegado el 23 de noviembre. La Revista de Ambos Mundos de Madrid se hizo eco de esta noticia en su sección de crónica política:

En noviembre llegó a Santo Domingo [...], el agente comercial de España, señor Saint-Just (sic). Recibido con la mayor cordialidad por el presidente D. Pedro Santana, obtuvo al día siguiente de su arribo, el competente execuátur, y empezó a ejercer inmediatamente sus funciones con gran júbilo de los naturales, los cuales, siempre fieles a la antigua madre patria, saludaron entusiasmados su bandera [...]. Asi han quedado reanudadas las relaciones de la península con la isla llamada, por excelencia, en otro tiempo isla Española; y ahora solo falta que un buen tratado las regularice, afiance y perpetúe $e^{40}$.

El ejecutivo de Santo Domingo, estimulado por la presencia del nuevo agente comercial de España y por la invitación que este le hizo en nombre de su gobierno, a fin de iniciar las negociaciones conducentes a la firma de un tratado entre ambos países, designó a Rafael María Baralt como enviado extraordinario y ministro plenipotenciario de la República Dominicana en Madrid. Mientras se desarrollaba dicha negociación, San Just comenzó su actividad publicando en los periódicos un anuncio, por medio del cual se invitaba a "los súbditos de S. M. a matricularse en la agencia comercial" de España, lo que fue aprobado por Luzuriaga en la comunicación que dirigió a aquel el 17 de enero de $1855^{41}$.

La medida adoptada por San Just, una práctica diplomática habitual que en circunstancias normales no habría tenido mayor importancia, en aquella situación tan

\footnotetext{
${ }^{39}$ Welles, La viña de Naboth..., vol. 1: 155-156.

40 “Crónica política”, Revista de Ambos Mundos 3 (1855): 267.

${ }^{41}$ Carta de Luzuriaga a San Just, Madrid, 17 de enero de 1855. AGA, sección Asuntos Exteriores, legajo 54/5224, carpeta n. ${ }^{\circ} 5$.
} 
convulsa estaba llamada a crear serios roces en las relaciones entre España y la República Dominicana, especialmente a partir de la firma del tratado dominico-español. La posibilidad de inscribirse en esta matrícula fue aprovechada por muchos partidarios de Báez para actuar contra el gobierno de Santana bajo la protección de la nacionalidad española, debido al carácter aún más autoritario y restrictivo de la nueva reforma constitucional promulgada en diciembre de 1854. Asimismo, esta fue la opción elegida por un cierto número de personas con algún pariente español, quienes buscaban evadir de ese modo las duras obligaciones militares que imponía el ejecutivo a todos los ciudadanos considerados aptos para prestar servicio en el ejército, so pretexto de la siempre latente amenaza haitiana, tal como se verá más adelante.

San Just llegó a Santo Domingo en medio de la lucha desatada entre los cónsules de Gran Bretaña y Francia, por un lado, y el general Cazneau, por el otro, en torno al control sobre la República Dominicana. Inmediatamente, el agente comercial empezó a informar al gobierno español acerca de la evolución de los hechos que estaban teniendo lugar en aquel país. Así, el 10 de diciembre de 1854 San Just alertó de que se esperaban fuerzas navales de Estados Unidos que "presionarían para obtener un acuerdo o, en caso contrario, tomarían por la fuerza la bahía de Samaná", en previsión de lo cual "Francia e Inglaterra también ordenarían a sus armadas en las Antillas que navegaran hacia la isla". El agente comercial comunicó estas noticias también al capitán general de Cuba, todo ello con el fin de que España, "en cuestión de tanto interés", pudiese "coadyuvar a las fuerzas de ambas naciones" 42 .

En su respuesta al despacho de San Just, Luzuriaga subrayó las líneas fundamentales que aquel debía seguir en su actuación: la base de la política del gobierno español en la cuestión que había surgido en Santo Domingo era "el más perfecto acuerdo" con Francia y Gran Bretaña. El ministro puso especial cuidado en recomendar a San Just la máxima prudencia, y en ese sentido le indicó que no entraba "por tanto en sus miras tomar aisladamente la iniciativa de una acción que si llegase el caso habría de ser mancomunada". Entretanto, Luzuriaga sugirió al agente comercial que, "asociándose oportunamente a las gestiones de las dos naciones referidas", mantuviera y acrecentara si fuese posible la legítima influencia de España. El ministro también comunicó a San

\footnotetext{
${ }^{42}$ Cristóbal Robles Muñoz, Paz en Santo Domingo (1854-1865). El fracaso de la anexión a España (Madrid: Consejo Superior de Investigaciones Científicas, 1987), 88-89. El autor cita la Carta de San Just a De la Concha, Santo Domingo, 10 de diciembre de 1854. AMAE, fondo Política, subfondo Política Exterior, serie República Dominicana, legajo H 2374.
} 
Just que Baralt había recibido los plenos poderes, e inmediatamente había comenzado a "tratarse confidencialmente de la negociación del tratado"43. Las instrucciones enviadas a dicho agente el 22 de enero de 1855 por vía de La Habana no debieron resultar demasiado eficaces, toda vez que llegaron a su destino tres meses más tarde, el 24 de abril, mientras que la comunicación inmediatamente anterior, la del 17 de enero, lo hizo en un plazo más normal para los medios de transporte de aquella época, y llegó a Santo Domingo el 23 de febrero.

Las soluciones barajadas por el gobierno dominicano para encauzar la complicada situación del país se limitaban a dos alternativas: "La de un tratado con los Estados Unidos, que afirmaba el rechazo de toda invasión haitiana, o la de un protectorado compartido entre España, Francia e Inglaterra”. Esta última posibilidad, en opinión de Santana, hacía "más urgente el reconocimiento de la independencia de Santo Domingo por parte de España", como hizo saber San Just al gobernador de Cuba el 24 de diciembre de 1854. Sin embargo, los gobernadores de Cuba y Puerto Rico "se alineaban con Juan Abril y eran partidarios de que España no reconociera a la República Dominicana ni participara en el protectorado". Por medio de una carta que escribió el 6 de diciembre al embajador de España en París, Abril le expresó su oposición a la firma de un tratado de reconocimiento dominico-español, porque el mismo dejaría abierta la puerta a otro con Estados Unidos. De la Concha también estaba al corriente de las gestiones que Raybaud seguía llevando a cabo y por ello consideró que, "gracias al éxito del cónsul francés, era innecesario el reconocimiento", según expuso a Luzuriaga el 12 de diciembre, puesto que él buscaba ante todo evitar problemas con Estados Unidos ${ }^{44}$. Con mayor cautela, y sin mostrar abiertamente su parecer, el 14 de diciembre Norzagaray encareció a San Just "la conveniencia de proceder con toda circunspección en lo relativo al reconocimiento de la independencia" dominicana por parte de España ${ }^{45}$.

En enero de 1855 lord Clarendon expresó al embajador norteamericano en Londres los buenos deseos de su gobierno respecto al de Estados Unidos, en un intento

\footnotetext{
${ }^{43}$ Carta de Luzuriaga a San Just, Madrid, 22 de enero de 1855. AGA, sección Asuntos Exteriores, legajo $54 / 5224$, carpeta . $^{\circ} 5$.

${ }^{44}$ Robles, Paz en Santo Domingo..., 88-89.

${ }^{45}$ Carta de De los Santos a San Just, Madrid, 6 de marzo de 1855 (De los Santos se encontraba al frente de la Dirección Política del Ministerio de Estado; el documento es un acuse de recibo de la Carta de San Just a De los Santos, Santo Domingo, 24 de diciembre de 1854). AGA, sección Asuntos Exteriores, legajo 54/5224, carpeta n. ${ }^{\circ} 5$.
} 
por echar a un lado las diferencias y recomponer las relaciones entre ambos países. Por su parte, el embajador Buchanan se lamentó ante el ministro de que, a pesar de sus palabras, la actitud británica fuese tan hostil a la firma de un acuerdo dominicoestadounidense, a lo cual Clarendon respondió que en el futuro no volvería a darse a Estados Unidos ningún motivo de queja ante una situación semejante. Esta postura contemporizadora de Gran Bretaña trajo como consecuencia un nuevo escenario, donde "la oposición abierta de los europeos a Estados Unidos quedó a cargo de España, como no tardaría en verse casi de inmediato" 46 .

E1 2 de febrero de 1855 San Just envió al ministro de Estado un número de la Gaceta de la República Dominicana, que contenía un artículo favorable a las pretensiones de Estados Unidos con relación a su establecimiento en ese territorio, y el 4 de abril Luzuriaga respondió al agente comercial en estos términos:

En vista de esto y de las noticias que V. S. comunica [...], el gobierno de S. M. se ha dirigido nuevamente a los gobiernos de Francia e Inglaterra para conocer la marcha que se proponga seguir, si ocurren las eventualidades que se temen, y proceder de acuerdo con dichas potencias. Entretanto obrará $V . S$. [...] entendiéndose con los agentes de Inglaterra y Francia, y cuidando de tener informado al capitán general de la isla de Cuba, de todo cuanto ocurra [...]. V. S. por su parte procederá con toda circunspección, si al fin se presentase en ese puerto un buque de guerra español, y procurará que en las gestiones que se practiquen para impedir tengan resultado las del general Cazneau aparezca la España secundando los esfuerzos de la Inglaterra y la Francia, y no promoviendo determinaciones con objeto de contrarrestar los proyectos de los Estados Unidos ${ }^{47}$.

Estas instrucciones no parecían indicar un cambio significativo en la línea seguida durante los meses anteriores por el gobierno español, pero las circunstancias acabarían obligándole a tomar parte en los asuntos dominicanos de forma mucho más activa. La situación se encontraba en una especie de punto muerto, del cual ninguno de los actores implicados sabía cómo salir sin provocar un enfrentamiento de mayor gravedad, una vez desechada la opción de un protectorado conjunto entre las tres naciones europeas.

\footnotetext{
${ }^{46}$ Pérez, Historia diplomática..., 286. El autor apoya su afirmación en Charles Callan Tansill, The United States and Santo Domingo, 1798-1873: a chapter in Caribbean diplomacy (Baltimore: The Johns Hopkins Press, 1938), 200-201.

${ }^{47}$ Carta de Luzuriaga a San Just, Madrid, 4 de abril de 1855. AGA, sección Asuntos Exteriores, legajo 54/5224, carpeta n. ${ }^{\circ} 5$.
} 
Gran Bretaña, según se deduce de la posición adoptada por Clarendon ante la queja del embajador norteamericano, había iniciado ya una retirada estratégica, y Francia no iba a tardar mucho tiempo en hacer lo mismo, dejando a España sola en la primera línea de fuego, aun contra el deseo de su gobierno, que siempre se había mostrado reacio a la hora de jugar un papel protagonista frente a Estados Unidos. E1 encargado de negocios en París, José España y Puerta, dio una prueba inequívoca de la nueva actitud francesa, en una comunicación dirigida el 14 de abril de 1855 al ministro de Estado, de cuyo contenido se informó inmediatamente a San Just. El representante español en dicha capital escribió lo siguiente:

Mr. Thouvenel me confirmó ayer lo que de un modo incidental me había dicho el 30 de marzo último [...] respecto del plan, que de intervenir de un modo grave en los negocios de Santo Domingo, se había atribuido al gobierno de los Estados Unidos a consecuencia de la misión con que fue a aquella isla su plenipotenciario el general Cazneau. En vista de las explicaciones y seguridades dadas por Mr. de Marcy a Mr. le comte de Sartiges, representante de Francia en Washington, explicaciones y seguridades que se creen aqui sinceras, el gobierno de este emperador no abriga por ahora ningún temor de que se realice entre las dos repúblicas tratado alguno contrario a los intereses de Francia, España e Inglaterra [...]. Mr. Thouvenel cree, pues, innecesarias actualmente nuevas instrucciones y convencido de que la conducta que había observado en este negocio el general Cazneau había sido desaprobada por su gobierno, me invitó a que tranquilizara al de S. M. sobre este punto, añadiendo, y sobre esto llamo la atención de V. E. porque puede convenir el tener presentes las disposiciones en que se halla este gabinete respecto al de Washington, para el arreglo de las diferencias [...] entre España y la república norteamericana, que importaba mucho a la Francia conservar las mejores relaciones, sobre todo en la actualidad, con los Estados Unidos, y no mostrar ningún género de desconfianza con nuevas instrucciones ${ }^{48}$.

Mientras en Europa los gobiernos francés y británico habían empezado a modificar su postura de abierto enfrentamiento con Estados Unidos, Cazneau presentó el 13 de febrero de 1855 un ultimátum al gobierno dominicano. El día 15 el gobierno le comunicó que ya "había enviado a Washington las observaciones que el Congreso había hecho al proyecto de tratado" y que estaba a la espera de su respuesta. Por supuesto, el general norteamericano protestó por considerar irregular el modo en que las autoridades

\footnotetext{
${ }^{48}$ Carta de De los Santos a San Just, Madrid, 29 de abril de 1855. AGA, sección Asuntos Exteriores, legajo 54/5224, carpeta n. ${ }^{\circ} 5$.
} 
de la República habían transmitido dichas observaciones a su gobierno, lo cual a su juicio demostraba una falta de "buena voluntad entre negociadores" por parte dominicana $^{49}$. Así pues, a pesar de todos sus esfuerzos y el interés de Santana por firmar un tratado con Estados Unidos, el fracaso de Cazneau no dejó al ejecutivo de Washington más opción que destituirlo. Sin embargo, esto no significaba en absoluto desistir del tratado ni de la obtención de un terreno en Samaná, sino que se pospuso para una mejor ocasión. Esta llegó pocos meses más tarde, en octubre de 1855, cuando Marcy ordenó al agente comercial norteamericano en Santo Domingo que actuase como agente especial, a fin de "conseguir la estación naval que Cazneau no había podido lograr un año antes"

\section{Un nuevo salto cualitativo: firma del tratado dominico-español en febrero de 1855 y primeros roces entre la República Dominicana y España}

Sin embargo, en el lapso transcurrido entre el final de aquella negociación y el comienzo de esta un nuevo factor había hecho su entrada en el escenario diplomático dominicano, un factor que necesariamente iba a incidir de modo sustancial en la evolución de los acontecimientos. El 18 de febrero de 1855 Rafael María Baralt, plenipotenciario del gobierno dominicano, y Claudio Antón de Luzuriaga, ministro de Estado, firmaron en Madrid el tratado de paz, amistad, comercio, navegación y extradición entre la República Dominicana y España. El mismo fue ratificado el 9 de mayo por el presidente Santana y el 2 de agosto siguiente por Isabel II, siendo canjeadas las ratificaciones el 19 de agosto de dicho año en El Escorial. Al publicar la noticia del tratado dominico-español, la Revista de Ambos Mundos hizo constar que para la firma de este:

Se han tenido a la vista, por una parte los que España ha celebrado con otras repúblicas de América, y por otra los que la

\footnotetext{
${ }^{49}$ Robles, Paz en Santo Domingo..., 91.

${ }^{50}$ Hauch, La República Dominicana y sus relaciones..., 110. El autor cita la Carta de Marcy a Elliot, s. 1., 5 de octubre de 1855, en William R. Manning, Diplomatic correspondence of the United States: interAmerican affairs, 1831-1860 (Washington: Carnegie Endowment for International Peace, 1935), vol. 6: 20-22. Véase también, sobre la segunda fase de negociación del tratado dominico-estadounidense a partir de octubre de 1855: Luis Alfonso Escolano Giménez, "El comienzo de la rivalidad internacional y de la injerencia española en la República Dominicana (1855-1856)", Revista de Indias 75, n. ${ }^{\circ} 265$ (2015), 715726, DOI: 10.3989/revindias.2015.022.
} 
República Dominicana ha hecho con Francia e Inglaterra: este tratado, decimos, fundado en la más estricta reciprocidad, consta de cuarenta y siete artículos y es, sin duda, el más completo, así también como el más ventajoso a las partes contratantes de cuantos hasta ahora se han celebrado entre España y sus ya emancipadas posesiones coloniales [...]. El reconocimiento es explícito e incondicional, como lo necesita y tiene derecho a pedirle la República Dominicana para legalizar su situación política y su ahora legítima e inconcusa posesión del territorio ${ }^{51}$.

Este tratado, por lo tanto, difería en gran medida de los modelos en que pueden agruparse el resto de los tratados hispanoamericanos, pues si bien es cierto que en aquel se insertaban todas las cláusulas que integraban estos, también aparecían otras muchas nuevas $^{52}$, que lo convertían en el más extenso, con mucho, de todos ellos.

No obstante, su importancia radica no tanto en la prolijidad de sus disposiciones, cuanto en las consecuencias que el propio reconocimiento produjo en el modo de actuar de España con respecto a la República Dominicana, sobre todo a partir de la llegada a Santo Domingo del primer cónsul, Antonio María Segovia, en diciembre de 1855. En efecto, este desplegó enseguida una intensa actividad contra el tratado dominicoestadounidense, cuya ratificación quedó en suspenso debido a las presiones del diplomático español sobre el ejecutivo de Santo Domingo. La política intervencionista del cónsul llegó incluso a provocar en octubre de 1856 la caída de Santana, quien fue sustituido por Báez, pues Segovia consideraba que este último sería mucho más favorable a los intereses de España por su oposición a un acercamiento entre la República Dominicana y Estados Unidos.

Este episodio es conocido en la historiografía dominicana como la matrícula de Segovia, que consistió en la nacionalización irregular de un número considerable de dominicanos partidarios de Báez, mediante la inscripción de estos como ciudadanos españoles en el registro de matrícula consular, para protegerlos frente a posibles represalias del régimen de Santana. De acuerdo con autores tales como Balcácer y García Arévalo, lo que hizo Segovia fue proceder, simplemente, "a la apertura de libros de registro en la sede del consulado para que todo el que deseara adoptar la nacionalidad

\footnotetext{
51 “Crónica política”, Revista de Ambos Mundos 3 (1855): 267.

52 Jorge Castel, El restablecimiento de las relaciones entre España y las repúblicas hispanoamericanas, 1836-1894 (Madrid: Cuadernos de historia de las relaciones internacionales y política exterior de España, 1955), 36.
} 
española, así lo hiciese", basando su actuación "en una interpretación antojadiza del artículo 7. ${ }^{\circ}$ del tratado" dominico-español ${ }^{53}$.

Sin embargo, dichos autores parecen obviar que existía una cierta indefinición en lo relacionado con la nacionalidad de algunos residentes en la República Dominicana que se declaraban españoles, una polémica cuestión que venía arrastrándose ya desde hacía tiempo, como se verá más adelante. Por ello habría que analizar si en realidad el mencionado artículo del tratado era tan claro como requerían las circunstancias, o si, por el contrario, dejaba demasiado espacio a la libre interpretación de cada cual, aunque cabe pensar que se trataba más bien de lo segundo ${ }^{54}$.

De hecho, el mismo día en que el nuevo ministro de Estado, Juan Zavala de la Puente, felicitó a Baralt tras recibir la noticia de la aprobación del tratado por parte del Senado dominicano, el diario La España, muy próximo al partido moderado, publicó un editorial que expresaba las numerosas interrogantes planteadas por la compleja situación política dominicana. El autor de este señaló en primer lugar que resultaba necesario regularizar cuanto antes las relaciones diplomáticas dominico-españolas, "a fin de evitar en lo sucesivo las reyertas y disputas desagradables" provocadas por la confusión y las complicaciones en todo lo relativo a la nacionalidad. Acto seguido, el editorialista del periódico resumió los últimos sucesos que habían ocurrido en la República Dominicana, en los cuales se encontraban involucrados presuntamente dos hombres, apellidados Dalmau y Camoin, quienes al parecer eran ciudadanos españoles. Además, aquel comentó la difícil posición de San Just en todo el asunto, ya que, partiendo del supuesto de que tanto Dalmau como Camoin eran españoles, el agente comercial había dirigido al ministro de Relaciones Exteriores dominicano una nota, protestando "contra el fusilamiento del uno y el encarcelamiento del otro". En su respuesta, el ministro sostuvo que las personas en cuyo favor había reclamado San Just eran ciudadanos dominicanos, pero el agente no consideró satisfactorias estas aclaraciones y volvió "a la carga con mayor energía si cabe que al principio" 55 .

\footnotetext{
53 Juan Daniel Balcácer y Manuel A. García Arévalo, La independencia dominicana (Madrid: Editorial Mapfre, 1992), 133.

${ }^{54}$ Escolano, "El comienzo de la rivalidad internacional...", 727. Para un estudio más pormenorizado sobre la llamada matrícula de Segovia, véase Amadeo Julián, "Rafael María Baralt. Su vida, obras y servicios prestados a la República Dominicana”, Clío 81, n. ${ }^{\circ} 183$ (enero-junio 2012): 79-86.

55 "Editorial", La España, 26 de junio de 1855.
} 
El mencionado editorial de La España subrayó asimismo que el conflicto de la nacionalidad debía abordarse con carácter de urgencia, dado que, en caso de no ser adecuadamente resuelto, amenazaba con tener consecuencias muy graves para las Antillas españolas. Precisamente, la seguridad y protección de estas posesiones eran el principal objetivo que perseguía el ejecutivo de Madrid mediante la firma del tratado con la República Dominicana. El editorialista concluyó con estas palabras:

Estamos muy lejos de reprobar [...] el celo de nuestros agentes en defensa de los súbditos españoles que se vean vejados o atropellados en país extranjero; pero ante todo es indispensable que la cualidad de españoles esté suficientemente acreditada, a fin de que la bandera nacional no sirva para cobijar desmanes de aventureros que buscan su medro en discusiones civiles a que deberían ser completamente extraños [...].

Sería por lo tanto muy sensible que un agente comercial, probablemente sin instrucciones precisas para tratar asuntos de tan delicada especie, sentase doctrinas y precedentes que los extranjeros pudiesen invocar en contra nuestra. Por eso insistimos de nuevo en la necesidad de arreglar pronto estas cuestiones, estableciendo claramente y sin que haya lugar a interpretación, la nacionalidad de la conveniente matricula que se abra al efecto ${ }^{56}$.

Así pues, en lugar de apaciguarse tras la firma del tratado, la cuestión de la matrícula de los ciudadanos españoles fue agriando más aún las relaciones entre el gobierno dominicano y San Just, hasta el extremo de que este mostró abiertamente su indignación en los despachos que dirigió a sus superiores. Por ejemplo, en una comunicación remitida a finales de mayo al gobernador de Puerto Rico, el agente denunció la persecución contra todo lo español llevada a cabo por el régimen de Santana, del cual aseguró que una vez arrojada la máscara no se detenía, sino que cada día se provocaba un nuevo conflicto que aumentaba "el protocolo de los ya consumados vejámenes”. San Just justificó la dureza de su lenguaje dada la gravedad de los hechos, y centró sus críticas en la situación de muchos españoles, quienes al llegar a territorio dominicano habían sido obligados a servir en el ejército, por lo que reclamaron la protección del agente comercial de España en Santo Domingo. Este acusó al gobierno dominicano de negarse a entregarles sus pasaportes, e incluso de mantenerlos bajo arresto para que no pudiesen informarle de su situación. Es más, el gobierno llegó incluso a amenazar a varias familias españolas por ir a matricularse, advirtiéndoles de

\footnotetext{
${ }^{56}$ Ibidem.
} 
que si lo hacían las expulsaría del país. Al final de semejante lista de ofensas que el régimen santanista había infligido a los españoles residentes en la República Dominicana, San Just se desahogó emitiendo las siguientes opiniones con relación al grupo dirigente de aquel país, así como respecto a la potencia que según él lo defendía y sostenía, es decir, Estados Unidos: "Es inaudito [...] lo que pasa en este país, gobernado por una reunión de hombres sin fe ni pundonor, y si la nación española no se dispone a dar un ejemplo, no concibo qué ocasión más propicia pueda ofrecerse [...]. Santana sin embargo sigue impávido porque cuenta con la fuerza de los negreros armados" ${ }^{\text {a }}$.

Estas intranquilizadoras noticias fueron transmitidas por el gobernador de Puerto Rico a Madrid, adonde llegaron a mediados de julio, aún con tiempo suficiente para al menos aplazar bien la ratificación bien la promulgación del tratado, en espera de una aclaración satisfactoria de tales hechos. No obstante, dicha posposición no tuvo lugar, sino que el gobierno español llevó a cabo las diligencias necesarias según el calendario previsto sin alteración alguna. En efecto, tras presentar el 2 de julio ante las Cortes un proyecto de ley solicitando autorización para ratificar el tratado que había firmado con el gobierno de la República Dominicana, el último requisito pendiente para que se convirtiera en ley era su promulgación oficial, la cual se produjo el 26 de julio. Diez días antes, Zavala comunicó a San Just que Antonio María Segovia había sido nombrado cónsul general y encargado de negocios de España en Santo Domingo ${ }^{58}$.

Por otra parte, De los Santos, quien encabezaba la Dirección Política del Ministerio de Estado, respondió en agosto a San Just, que había informado en varias comunicaciones sobre la actitud del gobierno dominicano con relación a los hijos de ciudadanos españoles, a los que se obligaba a tomar las armas desde los 14 años. De los Santos dio instrucciones al agente para que reclamara con energía frente a dichos abusos, y le subrayó la necesidad de formular tales reclamaciones para proteger a todos los individuos que fuesen realmente españoles, así como mantenerse firme frente a la persecución del gobierno dominicano contra ellos ${ }^{59}$.

\footnotetext{
57 Luis Alfonso Escolano Giménez, "El comienzo de las relaciones diplomáticas entre España y la República Dominicana en 1855”, Revista Complutense de Historia de América 37 (2011): 297, DOI: 10.5209/rev_rcha.2011.v37.12.

${ }^{58}$ Escolano, "El comienzo de las relaciones diplomáticas...”, 297-298.

${ }^{59}$ Escolano, "El comienzo de las relaciones diplomáticas...", 298.
} 
En tales circunstancias no parece sorprendente que el gobierno español mantuviera inalterado su proyecto inicial de establecer relaciones diplomáticas con la República Dominicana, pese a las complicaciones que le transmitió San Just, pues lo creía imprescindible a fin de influir mucho más efectivamente sobre la política de Santana y tratar así de estorbar su acercamiento a Estados Unidos. De hecho, la defensa de los intereses españoles en Cuba y Puerto Rico ante la siempre ambiciosa potencia norteamericana fue precisamente lo que había llevado al ejecutivo de Madrid a estrechar lazos con el de Santo Domingo. Por consiguiente, no resultaba lógico malograr el plan que ya se encontraba en marcha tan solo por una sucesión de obstáculos cuya trascendencia era, en cualquier caso, mucho menor sin duda que el objetivo prioritario de España, el cual consistía por supuesto en preservar a toda costa sus valiosas posesiones antillanas.

\section{CONCLUSIONES}

En definitiva, la historia de la República Dominicana desde su independencia respecto a Haití en 1844 hasta, por lo menos, 1871, cuando fracasó el intento de anexión del territorio dominicano a Estados Unidos, viene definida por una serie de factores básicos. El más determinante de ellos fue sin duda la crisis estructural del nuevo estado como consecuencia de su inestabilidad política y debilidad económica. Esta crítica situación condujo a los diversos gobiernos del país a buscar la ayuda de una potencia extranjera, por medio del protectorado o el establecimiento de relaciones diplomáticas, o incluso, como sucedió entre 1861 y 1865, mediante su reincorporación a España, cuyo principal objetivo en el Caribe era ante todo conservar Cuba y Puerto Rico ${ }^{60}$.

El segundo elemento que marcó dicha etapa es la constante amenaza a la independencia dominicana por parte de Haití, materializada en varias invasiones del país vecino contra su territorio hasta la tregua de 1856, a partir de la cual el ejecutivo de Puerto Príncipe comenzó a emplear otras tácticas más sutiles para socavar la independencia dominicana. Así pues, las gestiones para obtener un acuerdo de paz

\footnotetext{
${ }^{60}$ Para ampliar al respecto, véase Luis Alfonso Escolano Giménez, La rivalidad internacional por la República Dominicana y el complejo proceso de su anexión a España, 1858-1865 (Santo Domingo: Mediabyte, 2013), http://website.agn.gov.do:8080/publicaciones/libro/rivalidad-internacional-republicadominicana-el-complejo-proceso-anexion-espana.
} 
duradero entre los dos países de la isla con la mediación de Francia, Gran Bretaña y Estados Unidos, a la que posteriormente se unió España, no fueron sino el comienzo de un prolongado periodo de injerencias externas en la política dominicana.

Este intervencionismo se vio alimentado, en primer lugar, por la rivalidad internacional existente entre dichas potencias, sobre todo entre las europeas por un lado y Norteamérica por el otro. En segundo lugar, la injerencia externa se vio estimulada asimismo en gran medida por una amenaza haitiana que, si bien algunas veces era muy real, en muchas otras ocasiones fue tan solo convenientemente magnificada por el ejecutivo de Santo Domingo para sus propios fines. En tercer lugar, esa intervención extranjera se debió también a las continuas luchas internas por el poder, que abrieron paso aún con más facilidad a un involucramiento cada vez mayor de los diversos agentes diplomáticos en las mismas. Por último, cabe afirmar que el inicio de una cierta consolidación de la soberanía dominicana, aunque todavía con numerosas limitaciones incluso en tiempos relativamente recientes, no se produjo hasta 1924, cuando las tropas estadounidenses que habían ocupado el territorio dominicano en 1916 abandonaron esa parte de la isla, tras una intensa campaña de reivindicación nacionalista.

\section{BIBLIOGRAFÍA}

Archivo Histórico Nacional (España). Papeles de Santo Domingo. Madrid: Dirección General de Bellas Artes y Archivos, 1985.

Balcácer, Juan Daniel y Manuel A. García Arévalo. La independencia dominicana. Madrid: Editorial Mapfre, 1992.

Castel, Jorge. El restablecimiento de las relaciones entre España y las repúblicas hispanoamericanas (1836-1894). Madrid: Cuadernos de las relaciones internacionales y política exterior de España, 1955.

Escolano Giménez, Luis Alfonso. "El comienzo de las relaciones diplomáticas entre España y la República Dominicana en 1855”. Revista Complutense de Historia de América 37 (2011): 277-299. DOI: 10.5209/revrcha. 2011.v37.12.

-- "El comienzo de la rivalidad internacional y de la injerencia española en la República Dominicana (1855-1856)”. Revista de Indias 75, n. 265 (2015): 711742. DOI: 10.3989/revindias.2015.022.

García, José Gabriel. Compendio de la historia de Santo Domingo. 4. ${ }^{\mathrm{a}}$ ed. Santo Domingo: ¡Ahora!, 1968.

González Calleja, Eduardo y Antonio Fontecha Pedraza. Una cuestión de honor. La polémica sobre la anexión de Santo Domingo vista desde España (1861-1865). Santo Domingo: Fundación García Arévalo, 2005. 
Hauch, Charles Christian. La República Dominicana y sus relaciones exteriores 18441882. Santo Domingo: Sociedad Dominicana de Bibliófilos, 1996.

Inarejos Muñoz, Juan Antonio. Intervenciones coloniales y nacionalismo español. La política exterior de la Unión Liberal y sus vínculos con la Francia de Napoleón III (1856-1868). Madrid: Sílex, 2010.

Jover Zamora, José María. La civilización española a mediados del siglo XIX. Madrid: Espasa-Calpe, 1992.

Julián, Amadeo. "La situación internacional, la crisis económica nacional y la misión Mella a España en 1854". En La sociedad dominicana durante la Primera República 1844-1861, editado por Tirso Mejía-Ricart G., 269-305. Santo Domingo: Universidad Autónoma de Santo Domingo, 1977.

-- "Rafael María Baralt. Su vida, obras y servicios prestados a la República Dominicana". Clio 81, n. ${ }^{\circ} 183$ (enero-junio 2012): 43-125.

Pérez, Carlos Federico. Historia diplomática de Santo Domingo (1492-1861). Santo Domingo: Universidad Nacional Pedro Henríquez Ureña, 1973.

Perkins, Dexter. La cuestión de Santo Domingo 1849-1865. Santo Domingo: Sociedad Dominicana de Bibliófilos, 1991 (facsímil de la 1. ed. en español. Ciudad Trujillo, República Dominicana: [Logia Cuna de América], 1955).

Pinto Tortosa, Antonio. Santo Domingo: una colonia en la encrucijada 1790-1820.

Madrid: Foro para el Estudio de la Historia Militar de España, 2017.

Robles Muñoz, Cristóbal. Paz en Santo Domingo (1854-1865). El fracaso de la anexión a España. Madrid: Consejo Superior de Investigaciones Científicas, 1987.

Welles, Sumner. La viña de Naboth. La República Dominicana 1844-1924. 4. a ed. Santo Domingo: Taller, 1981.

\section{FUENTES}

Archivo del Ministerio de Asuntos Exteriores, Unión Europea y Cooperación, Madrid (AMAE), fondo Política, subfondo Política Exterior, serie República Dominicana, legajo H 2373.

Archivo General de la Administración, Alcalá de Henares (AGA), sección Asuntos Exteriores, legajo 54/5224.

Archivo Histórico Nacional, Madrid (AHN), sección Ultramar, Santo Domingo, legajo 3524.

"Crónica política". Revista de Ambos Mundos 3 (1855): 267.

"Editorial”. La España, 26 de junio de 1855. 